\title{
Hepatocystis in Hypsignatbus monstrosus (Pteropinea) in Gaboon
}

\author{
I. Hepatocystis malaria in a hammerhead \\ bat population in Gaboon, West Africa
}

\author{
by S. C. AYALA *, J. BRADBURY ** and S. BRADBURY ** \\ * Universidad del Valle, Medical School, Dept. Microbiologia, \\ Tulane University ICMR, A. Aereo 5390, Cali, Colombia \\ ** Department of Biology, University of California at San Diego, La Jolla, California, U.S.A.
}

SUMMARY. Blood smears from 142 Hypsignathus monstrosus collected from one site in Gaboon were examined; 139 bats showed Hepatocystis infection; it seems that all animals have acquired Hepatocystis infection by the time they are 6 months of age. Intensity of parasitemias varies according to age, sex and for females to their reproductive status.

Hepatocystis d'Hypsignathus monstrosus au Gabon. I. Infection à Hepatocystis dans une population de Rhinolophes (R. ferrum-equinum) au Gabon.

RESUME. Les frottis sanguins de 142 Hypsignathus monstrosus capturés au Gabon dans un même gîte ont été examinés ; 139 individus étaient parasités par Hepatocystis ; tous les animaux semblent avoir acquis leur infection avant l'âge de 6 mois. L'intensité de la parasitémie varie en fonction de l'âge, du sexe et des phases de reproduction chez la femelle.

Acknowledgement : Carmen Elena Varela helped examine the blood smears in Cali. Accepté le 8 mai 1980. 
As part of a study of the reproductive biology of the hammerhead bat Hypsignathus monstrosus, we have examined for hemoparasites blood smears from 142 bats netted at a single site in Gabon between June 12 and July 29, 1974. Life-table evaluations of the population suggested that mortality was much higher than would be expected for such a large bat. Food scarcity almost certainly causes stress on reproductively active individuals and this, if compounded by widespread infectious disease, could explain the surprisingly low survival rates.

All but 3 of the 142 slides examined showed Hepatocystis infections. The gametocytes and tissue stages of the parasite, permitting a specific identification and designation of this as a distinct species, are described in the accompanying paper (part II).

Parasitaemias ranged from scarcely detectable to $1.0 \%, x=0.03 \%$. Variation in intensity according to age was slight, except for consistantly lower parasitaemias in the 12 to 14 month old cohort $(x=0.06 \%)$ and in older females. Overall parasitaemia was lower in females $(\overline{\mathrm{x}}=0.09 \%, n=71)$ than males $(\overline{\mathrm{x}}=0.17 \%, n=61)$, and this was especially noticeable in animals 18 months or older : $0.08 \%$ in females versus $0.2 \%$ in males. Intensity was also lower in pregnant $(0.05 \%, n=24)$ than in reproductively inactive females $(0.14 \%, n=22)$ and intermediate in females carrying young $(0.10 \%, n=24)$.

Apparently, in this population nearly all animals have already acquired Hepatocystis infections by the time they are 6 months of age. This seems well suited to accomodate the parasite to a host population with such high reproductive rate (2 young per year per female) and rapid population turnover.

La $2^{\mathrm{e}}$ partie de cet article a déjà paru dans les Annales de Parasitologie, 1980, t. 55, $\mathrm{n}^{\circ} 5$, pp. $485-490$, en raison d'irrégularité du courrier postal. 